\title{
Phytochemical Composition of Cassia Alata Leaf Extract and its Effect on the Histology of the Pancreas of Diabetic wistar Rats
}

\author{
Chisom Favor Eliakim-Ikechukwu1, * Asukwo Asukwo Edem², \\ Uduak Monday William ${ }^{3}$, Stephen Odey Okori ${ }^{4}$, Churchill Jonadab Ihentuge ${ }^{5}$ \\ ${ }^{1,2,3,4}$ Department of Anatomy, College of Medical Sciences, University of Calabar, Cross River state, Nigeria \\ ${ }^{5}$ Department of Anatomy, Imo State University, Owerri, Imo state, Nigeria
}

\begin{abstract}
This study intends to validate the local use of cassia alata in the management of diabetes by quantitatively analyzing the phytochemicals present and its effect on blood sugar level and the histology of destroyed pancreatic islet cells.

$50 \mathrm{~g}$ of fresh leaves of cassia alata were used for phytochemical and nutritional analyses while the remaining leaves were dried and blended into fine powder. Bioactive substances in the herb were extracted with $80 \%$ ethanol. The herb extract was reinstituted with normal saline before administration to the rats.

Twenty-four wistar rats of both sexes with average weight of $160 \mathrm{~g}$ were used in this study. The rats were randomly divided into three parallel groups of diabetic and non-diabetic rats. The non-diabetic groups were designated $A_{N}, B_{N}$ and $C_{N}$ while the diabetic groups were designated $A_{D}, B_{D}$ and $C_{D}$. Rats in groups $A\left(A_{N}\right.$ and $A_{D}$ ) served as control for each parallel group and received $0.4 \mathrm{ml}$ of normal saline. Rats in the 2 parallel groups of $B\left(B_{N}\right.$ and $\left.B_{D}\right)$ received singe daily doses of $500 \mathrm{mg} / \mathrm{kg}$ body weight of ethanolic leaf extract of cassia alata via orogastric tube while rats in groups $C\left(C_{N}\right.$ and $\left.C_{D}\right)$ received subcutaneous injection of 5IU/kg body weight of human insulin daily. All the rats received water freely and normal rat feeds. The experiment lasted for twenty-eight days. The rats were sacrificed and pancreatic tissue taken for histological studies. Histological sections were stained with Haematoxylin and Eosin staining techniques. Experimental diabetes was induced using a single intraperitoneal injection of $65 \mathrm{mg} / \mathrm{kg}$ body weight of streptozotocin. Results revealed the presence of varying quantities of saponins, flavonoids, tannins, oxalate and alkaloids. Blood sugar level also reduced in both the diabetic and non-diabetic groups and histology revealed regeneration of destroyed pancreatic islet cells. It can be inferred that cassia alata potentiates the regeneration of beta cells in the pancreas of diabetic rats and has hypogycaemic effect. These antidiabetic effects may have been brought about by its rich phytochemical composition.
\end{abstract}

Keywords: Cassia alata, phytochemical, pancreatic islet cell.

\section{Introduction}

Diabetes mellitus is a chronic metabolic disease and for now there is no substantive cure. Many plant products have been used locally to bring about beneficial antidiabetic effects but most have not been screened to know the bioactive components that may be responsible for these effects. Recently the search for appropriate hypoglycaemic agents has been focused on plants used in traditional medicine[1].

Natural compounds with antidiabetic activity include complex carbon hydrates, alkaloids, glycopeptides, amines, flavonoids, sulphur compounds and inorganic ions. The antidiabetic mechanisms are numerous including activation of regeneration of functional pancreatic beta cells thereby increasing the number of insulin producing pancreatic beta cells[2], inhibition of insulinase activity[3],possession of insulin-like polypeptides [4] which will mimic the action of insulin, interference with carbohydrate absorption by the plant fibre[5], stimulation of insulin secretion in pancreatic beta cells[6] and increase in glycogen storage[7]. Cassia alata is a beautiful flowering shrub, a member of genus cassia belonging to the family of caesalpiniaceae. It is commonly known as candle bush. Different parts of the plant have been used for a wide spectrum of diseases. The leaves have been reported to possess anti-inflammatory and hypoglycaemic actions[8].

This study seeks to validate the traditional use of this herb by screening for the bioactive components of the leaves and its effect on destroyed beta cells of the pancreas.

\subsection{Plant material}

\section{Methodology}

Fresh leaves of Cassia alata were harvested locally in the month of July and taken to the botanical garden of the University of Calabar for authentication and acquisition of a voucher number. The leaves were and air dried at room temperature. 50g of the fresh leaves were used for analysis of the phytochemical composition, nutritional and mineral contents. The methods for these analysis were described by AOAC[9] and Harbone[10]. 
Dried leaves of Cassia alata were blended to fine powder and 570g of the powder was extracted with $80 \%$ of alcohol. The oily brown extract was refrigerated until use. For administration, the extract was reconstituted with normal saline.

\subsection{Animals}

Twenty-four presumably healthy wistar rats of both sexes with average weight of $160 \mathrm{~g}$ were bred in the animal house of the department of Anatomy, University of Calabar, Calabar. The rats were randomly divided into three parallel groups of non-diabetic $\left(A_{N}, B_{N}\right.$ and $\left.C_{N}\right)$ and diabetic $\left(A_{D}, B_{D}\right.$ and $\left.C_{D}\right)$ groups. Table 1 shows the experimental protocol. The experiment lasted for twenty-eight days.

Table 1: Showing the experimental protocol

\begin{tabular}{|c|c|c|c|c|c|c|}
\hline & \multicolumn{3}{|c|}{ Non-diabetic Groups } & \multicolumn{3}{|c|}{ Diabetic Groups } \\
\hline & $\begin{array}{l}A_{N} \\
\text { Negative } \\
\text { control }\end{array}$ & $\mathrm{B}_{\mathrm{N}}$ & $\mathrm{C}_{\mathrm{N}}$ & $\begin{array}{l}A_{D} \text { Positive } \\
\text { control }\end{array}$ & $\mathrm{B}_{\mathrm{D}}$ & $C_{D}$ \\
\hline No. of rats & 4 & 4 & 4 & 4 & 4 & 4 \\
\hline $\begin{array}{l}\text { Treatment } \\
\text { received/Route } \\
\text { of } \\
\text { administration }\end{array}$ & $\begin{array}{l}0.4 \mathrm{ml} \quad \mathrm{N} / \mathrm{S} \\
\text { (oral) }\end{array}$ & $\begin{array}{l}500 \mathrm{mg} / \mathrm{k} \\
\mathrm{g} \text { bwt of } \\
C A \text { (oral) }\end{array}$ & $\begin{array}{l}5 \mathrm{IU} / \mathrm{kg} \text { bwt. } \\
\text { of insulin } \\
\text { (subcut.) }\end{array}$ & $\begin{array}{ll}0.4 \mathrm{ml} & \mathrm{N} / \mathrm{S} \\
\text { (oral) } & \end{array}$ & $\begin{array}{l}500 \mathrm{mg} / \mathrm{kg} \\
\text { bwt of } C A \\
\text { (oral) }\end{array}$ & $\begin{array}{l}5 \mathrm{IU} / \mathrm{kg} \text { bwt. } \\
\text { of insulin } \\
\text { (subcut) }\end{array}$ \\
\hline
\end{tabular}

Bwt: body weight, CA: Cassia alata, N/S: Normal saline,Subcut: Subcutaneous

Apart from the daily treatment of the animals with cassia alata extract, normal saline and insulin, the animals were given freely fed with normal rat feeds.

\subsection{Induction of experimental diabetes}

Experimental diabetes was induced with a single dose of $65 \mathrm{mg} / \mathrm{kg}$ body weight intraperitoneal injection of streptozotocin reconstituted in normal saline after an overnight fast. Non-diabetic rats were injected with only normal saline. 72 hours post induction the fasting blood sugar (FBS) was estimated using fintest glucometer. Blood was collected from the tail vein of the rats. Rats with FBS greater than $13.3 \mathrm{~mol} / \mathrm{L}$ were judged to be diabetic[11] and were used for this study. FBS was monitored weekly.

At the end of the 28 days, the rats were fasted overnight and then anaesthesized using chloroform inhalation. Thereafter, a midline incision was made and the peritoneum stripped open. The pancreas was carefully dissected out and fixed in $10 \%$ formal saline Routine histological tissue processing was done and haematoxylin/eosin staining technique was employed.

Statistical analysis was done using the students t-test.

Results are presented in the tables below

\section{Results}

\subsection{Effect of Cassia alata on mean body weight.}

From Table 2, the negative control group $\left(A_{N}\right)$ and the groups that received insulin $\left(C_{N}\right.$ and $\left.C_{D}\right)$ showed appreciable weight gain but there was significant weight loss in the groups that received cassia alata $\left(\mathrm{B}_{\mathrm{N}}\right.$ and $\left.B_{D}\right)$ and the diabetic control groups $\left(A_{D}\right)$ at $P<0.05$. The percentage weight gains in groups $A_{N}, C_{N}$ and $C_{D}$ are $9.58 \%, 10.32 \%$ and $4.32 \%$ respectively. These were not significantly different at $\mathrm{P}<0.05$. The percentage weight losses in groups $\mathrm{B}_{\mathrm{N}}, \mathrm{A}_{\mathrm{D}}$ and $\mathrm{B}_{\mathrm{D}}$ are $6.52 \%, 20.31 \%$ and $9.23 \%$ respectively and when compared with the negative control group $\left(\mathrm{A}_{\mathrm{N}}\right)$ these weight losses are significantly different at $\mathrm{P}<0.05$. A significant difference also exist between groups $A_{D}$ and $B_{D}$ at $P<0.05$.

Table 2: Showing the mean body weight of the rats at the beginning and end of the experiment

\begin{tabular}{|l|l|l|l|l|l|l|}
\hline & \multicolumn{5}{|l|}{ Non-diabetic Groups } & \multicolumn{2}{l|}{ Diabetic Groups } \\
& $\begin{array}{l}\mathrm{A}_{\mathrm{N}} \\
\text { weight in g }\end{array}$ & $\begin{array}{l}\mathrm{B}_{\mathrm{N}} \\
\text { weight in g }\end{array}$ & $\begin{array}{l}\mathrm{C}_{\mathrm{N}} \\
\text { Weight in } \mathrm{g}\end{array}$ & $\begin{array}{l}\mathrm{A}_{\mathrm{D}} \\
\text { Weight in g }\end{array}$ & $\begin{array}{l}\mathrm{B}_{\mathrm{D}} \\
\text { weight in g }\end{array}$ & $\begin{array}{l}\mathrm{C}_{\mathrm{D}} \\
\text { Weight in g }\end{array}$ \\
\hline $\begin{array}{l}\text { Beginning } \\
\text { of } \\
\text { experiment }\end{array}$ & $160.00 \pm$ & $161.20 \pm$ & $\begin{array}{l}158.33 \pm \\
1.22\end{array}$ & $\begin{array}{l}160.00 \pm \\
0.00\end{array}$ & $\begin{array}{l}162.50 \pm \\
1.22\end{array}$ & $\begin{array}{l}160.30 \pm \\
1.73\end{array}$ \\
\hline $\begin{array}{l}\text { End of } \\
\text { experiment }\end{array}$ & 1.00 & 0.12 & & & & \\
\hline
\end{tabular}

Values are mean weight \pm SEM. * Significant at $\mathrm{P}<0.05$ 


\subsection{Effect of cassia alata on the mean fasting blood sugar}

From Table 3. diabetic groups $B_{D}$ and $C_{D}$ showed a significant drop in FBS at $p<0.05$ back to normal when compared with the negative control groups $\left(A_{N}\right)$. The FBS of the diabetic control group $\left(A_{D}\right)$ remained significantly high at $p<0.05$. The non-diabetic animals in group $B_{N}$ that received the herb extract developed hypoglycaemia.

Table 3: Showing the mean fasting blood sugar (FBS) of the rats at the beginning and end of the experiment

\begin{tabular}{|l|l|l|l|l|l|l|}
\hline & \multicolumn{5}{|l|}{ Non-diabetic Groups } & \multicolumn{2}{l|}{ Diabetic Groups } \\
\hline & $\begin{array}{l}\mathrm{A}_{\mathrm{N}} \\
(\mathrm{mmol} / \mathrm{l})\end{array}$ & $\begin{array}{l}\mathrm{B}_{\mathrm{N}} \\
(\mathrm{mmol} / \mathrm{l})\end{array}$ & $\begin{array}{l}\mathrm{C}_{\mathrm{N}} \\
(\mathrm{mmol} / \mathrm{l})\end{array}$ & $\begin{array}{l}\mathrm{A}_{\mathrm{D}} \\
(\mathrm{mmol} / \mathrm{l})\end{array}$ & $\begin{array}{l}\mathrm{B}_{\mathrm{D}} \\
(\mathrm{mmol} / \mathrm{l})\end{array}$ & $\begin{array}{l}\mathrm{C}_{\mathrm{D}} \\
(\mathrm{mmol} / \mathrm{l})\end{array}$ \\
\hline $\begin{array}{l}\text { Beginning } \\
\text { of } \\
\text { experiment }\end{array}$ & $3.91 \pm$ & $4.15 \pm$ & $6.73 \pm$ & $17.52 \pm$ & $18.00 \pm$ & $25.67 \pm$ \\
\hline $\begin{array}{l}\text { End of } \\
\text { experiment }\end{array}$ & 0.30 & 0.33 & 0.44 & 0.73 & 1.60 & 1.30 \\
\hline
\end{tabular}

Values all mean \pm SEM; $*$ Significant at $\mathrm{P}<0.05$

\subsection{Proximate Composition of cassia alata}

Table 4 showed that cassia alata leaves contain $68.80 \pm 0.32 \%$ moisture content and $31.20 \pm 0.17 \%$ dry matter out of the percentage dry matter, the carbohydrate, protein, fat, fibre and ash contents were $51.47 \pm$ $0.29,13.65 \pm 0.02,7.28 \pm 0.01,21.38 \pm 0.14$ and $6.22 \pm 0.01$ respectively.

Table 4: Showing percentage proximate composition of cassia alata leaves.

\begin{tabular}{|l|l|l|l|l|l|l|}
\hline Carbohydrate & Protein & Fat & Fibre & Moisture content & $\begin{array}{l}\text { Dry } \\
\text { matter }\end{array}$ & Ash \\
\hline $51.47 \pm$ & $13.65 \pm$ & $7.28 \pm$ & $21.38 \pm$ & $68.80 \pm$ & $31.20 \pm$ & $6.22 \pm$ \\
0.29 & 0.02 & 0.01 & 0.14 & 0.32 & 0.17 & 0.01 \\
\hline
\end{tabular}

Values are mean+S.E.M; $\mathrm{n}=3$.

\subsection{Phytochemical Composition of cassia alata}

Quantitative phytochemical analysis( table 5) revealed the presence of alkaloids, flavonoids, saponins, tannins, phenols, oxalates and phytates. These bioactive substances have been known to exert their actions on the biochemical activities of the body and by so doing may alter certain body functions.

Table 5: Showing the percentage Phytochemical Composition of cassia alata

\begin{tabular}{|l|l|l|l|l|l|l|}
\hline Alkaloids & Flavonoids & Saponin & Tannin & Phenol & Oxalate & Phytate \\
\hline $1.14 \pm$ & $0.36 \pm$ & $1.14 \pm$ & $0.34 \pm$ & $0.28 \pm$ & $0.26 \pm$ & $0.34 \pm$ \\
0.12 & 0.02 & 0.12 & 0.02 & 0.01 & 0.02 & 0.02 \\
\hline
\end{tabular}

Values are mean \pm S.E.M; $n=3$.

\subsection{Quantitative Mineral Composition of cassia alata leaves}

From table 6, cassia alata leaves contain potassium, calcium, sodium, magnesium and phosphorus in the following proportions $428.40 \pm 4.25,62.40 \pm 0.35,22.30 \pm 0.14,36.80 \pm 0.18,498.60 \pm 4.27 \mathrm{mg} / 100 \mathrm{~g}$

Table 6: Showing the quantitative mineral composition of cassia alata leaves

\begin{tabular}{|l|l|l|l|l|}
\hline Potassium & Calcium & Sodium & Magnesium & Phosphorus \\
\hline$(\mathrm{mg} / 100 \mathrm{~g})$ & $(\mathrm{mg} / 100 \mathrm{~g})$ & $(\mathrm{mg} / 100 \mathrm{~g})$ & $(\mathrm{mg} / 100 \mathrm{~g})$ & $(\mathrm{mg} / 100 \mathrm{~g})$ \\
\hline $428.40 \pm$ & $62.40 \pm$ & $22.30 \pm$ & $36.80 \pm$ & $498.60 \pm$ \\
4.25 & 0.35 & 0.14 & 0.18 & 4.27 \\
\hline
\end{tabular}

Values represent mean \pm S.E.M; $n=3$

\subsection{Effect of cassia alata leaf extract on the pancreas}

Photomicrographs reveal the effect of cassia alata extract on the pancreas.

Plate 1 (Group $A_{N}$ Negative Control) 
Stain: H/E magnification x 400

Photomicrograph reveals:

Numerous pancreatic acini

Islet of Langerhans (arrow) with a distinct capsule

Plate 2 (Group $\mathrm{B}_{\mathrm{N}}$ - received $500 \mathrm{mg} / \mathrm{kg}$ bwt of cassia alata leaf)

Stain: H/E magnification $\mathrm{x} 400$

Photomicrograph reveals:

Normal islet of Langerhans(arrow)

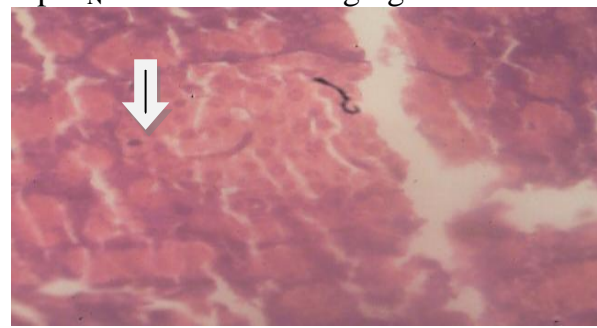

Plate 3 (Group $\mathrm{C}_{\mathrm{N}}$ received 5IU/kg bwt of insulin)

Stain: H/E magnification x 400

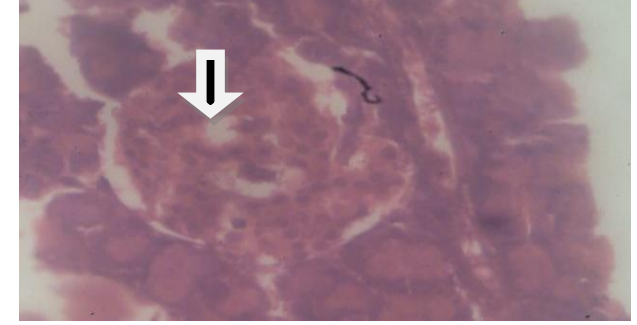

Photomicrograph reveals:

Numerous pancreatic acini

Islet of Langerhans(arrow) with clusters of cell

Plate 4 (Group $A_{D}$ - diabetic Control)

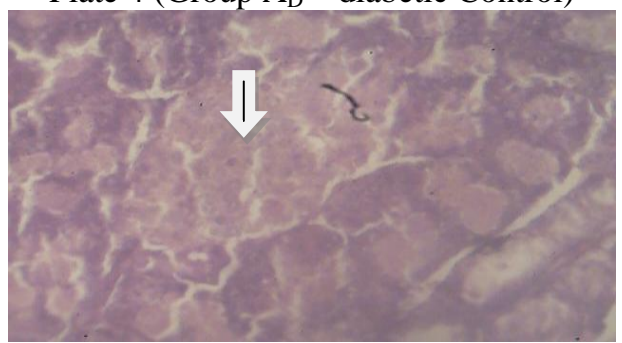

Stain: H/E magnification x 400

Photomicrograph reveals:

Pale stained nuclei in the islet of Langerhan(arrow)

Hypocellular and atrophic islets of Langerhan. 
Plate 5 (Group $\mathrm{B}_{\mathrm{D}}$ received $500 \mathrm{mg} / \mathrm{kg}$ bwt of cassi alataa leaf extract)

Stain: H/E magnification x 400

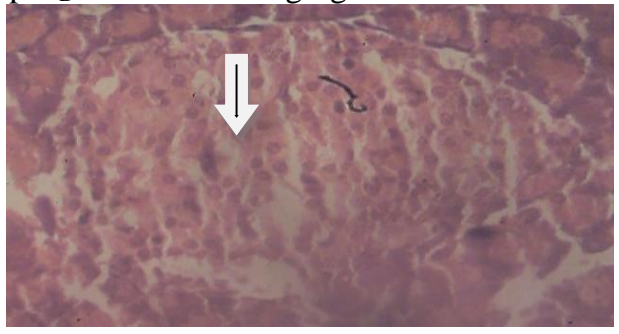

Photomicrograph reveals:

Increase in islet cell mass with distinct capsule

Increase in number of cells islet of Langerhan(arrow)

Plate 6 (Group $C_{D}$ - received $5 \mathrm{IU} / \mathrm{kg} / \mathrm{bwt}$ of insulin

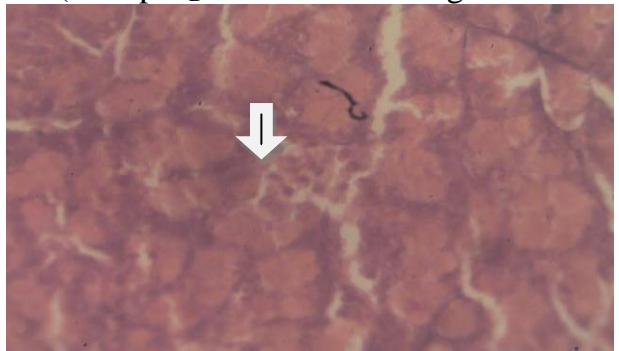

Stain: H/E magnification x 400

Photomicrograph reveals:

Numerous pancreatic acini (A)

Small volume islet of Langerhan(arrow)

\section{Discussion}

Weight changes is one of the features of diabetes. The hallmark of a poorly controlled diabetes is weight loss. It has been noted that patients with pervious poor glycaernic control who started newly on insulin had increase in weight[12],[13]. Weight loss was observed in the diabetic control group in this study which has also been reported by other researchers[14],[15],[16].

The groups treated with cassia alata had significant weight losses when compared with the nondiabetic control even with good glycaenic control so contradicting the relationship between glycaemic control and weight gain. Previous studies with cassia alata isolated Naringenin which stimulated a significantly higher glucose uptake activity and causes lipolysis in adipocytes both in the presence and absence of insulin[17]. This weight reduction effect of cassia alata may be good in the management of type II diabetes.

In this study, cassia alata exerted a hypoglycaemic and antihyperglycaemic effect. These effects have been reported in other studies using other herbs[18],[19],[20],[21]. Several mechanisms have been proposed for these effects. Nelson et al.,[5] reported that plants exert their antihyperglycaemic effect by interfering with carbohydrate absorption by plant. In this study cassia alata was found to have high fibre content. Another proposed mechanism is by the action of phytochemicals of plants. Earlier studies have established that saponin and flavonoids isolated from plants exhibit hypoglycaemic effect by increasing insulin release from pancreatic beta cells, increasing peripheral glucose uptake and by reducing glucose absorption[22],[23],[24]. Bolkent et $a l .,[25]$ and Diatewa et al.,[26] have reported that alkaloids and some saponins isolated from various medicinal plants have blood glucose reduction effect. Saponins have also been reported to enhance natural resistance and recuperative powers of the body[27]. Tannins and phenol are insulin - like substances[28],[29] and mimic the effect of insulin on glucose metabolism and enhanced insulin secretion. These substances have been isolated from cassia alata leaf in this study. Another possible way by which cassia alata may have exerted its hypoglycaemic and antihyperglycaemic effect may be by attenuating the body antioxidant system. Flavonoids, saponins and alkaloids have potent antioxidant activities. Hyperghycaemia generates glucose auto-oxidation and auto-oxidative glycosylation of proteins which leads to increased oxidative stress by increasing reactive oxygen species[30]. The increased oxidative stress results to depletion of majority of plasma antioxidants[31],[32],[33]. Expression of antioxidant enzymes is known to be very low in islet cells compared with other tissues and cells[34], therefore, once beta cells face oxidative stress they may be rather sensitive to it suggesting that oxidative stress may in part mediate toxicity of hyperglycaemia. It is not surprising therefore, that the blood 
sugar of the diabetic control group increased instead of reducing while the group that was treated with cassia alata leaf extract achieved good glycaemic control.

The presence of magnesium in cassia alata may have also contributed to the glycaemic control. Magnesium is a co-factor in various enzyme pathways involved in glucose oxidation and it modulates glucose transport across cell membrane. Its deficiency is common in patients with diabetes[7]. It may increase insulin secretion[35],[36]. A decrease in fasting blood glucose and increase in postprandial insulin have been reported with magnesium supplementation[37],[38]. Calcium, which was also isolated from the plant material also counteracts the autoimmune deficiency abnormality that is associated with type I diabetes and helps to normalize blood sugar levels in type II disease[39]. The changes seen in diabetic islet cells have also been reported by other researchers who have worked with other plant materials[21],[40],[41],[42],[43].

\section{Conclusion}

Cassia alata leaf has been found to have great beneficial antidiabetic effects which is brought about by its wide array of proximate, mineral and phytochemical constituents. Results from this study therefore validates the traditional use of this plant material for the management of diabetes. Purification and standardization of this herb for clinical trails will be an advancement towards providing a cheap, accessible and effective therapy for the management of both type I and type II diabetes.

\section{Reference}

[1] S.M. Rates. Plants are source of drugs. Toxicology, 39(5), 2001, 603-631

[2] M. A. Abdel, M. El-Feki and E. Salah. Effect of Nigella Sativa, Fish oil and Glidazide on alloxan diabetic rats, 1-Biochemical and Histopathological studies. Journal of Egyptain German Society of Zoology, 23, 1997, 237-265.

[3] M. B. Bhide, and R. Aiman Mechanism of action of oral antidiabetic drugs: potentiation of plasma effect and insulin effect on glucose uptake of the rat diaphragm. Indian Journal of Medical Researcher, 51, 1963, 733 - 736.

[4] E. Collier, A. Watkinson, C. F. Cleland and J. Roth. Partial purification and characterization of an insulin - like material from spinach and Lemnagibba, Journal of Biological chemistry, 262, 1987, 238 - 6247.

[5] R. W. Nelson, S. L. Ihle, L.D. Lewis, S. K. Salisburg, T. Miller, Bergdall and G. D. Bottoms. Effects of dietary fibre supplementation on glycemic control in dogs with alloxan-induced diabetes mellitus. American Journal of veterinary Research, 52 (12), 1991, 2060 - 2066.

[6] A. Kawano, H. Nakamura, S. I. Hata, M. Minakawa, Y. Miura, and K. Yagasaki. Hypoglycemic effect of aspalathin, a rooibos tea component from Aspalathus Linearis in type 2 diabetic model db//db mice.. Phytemedicine, 16 (5), 2009,437 - 443.

[7] G. Y. Yeh, D. M. Eisenberg, T. J. Kaptchuk and R. S. Phillips. Systematic review of herbs and dietary supplements for glycemic control in diabetes. Diabetes Care, 26 (4), 2003, 127 - 1294.

[8] E. M. Hasan, S. N. Islank, A. Hussian. Antibacterial activities of the leaves and stem-bark of Cassisa alata L. Bangladesh Journal of Botany, 17 (2), 1988, 135-139.

[9] AOAC. Official methods of analysis of the Association of Analytical chemists. 15th ed. Washington D C: association of official Analytical chemists, 1990.

[10] J. B. Harbone. Phytochemical methods, a guide to modern techniques of plant analysis. $3^{\text {rd }}$ ed. London, Chapman and Hall, 1990.

[11] A. A. Cetto, H. Weidenfeld, M. C. Revilla and I. A. Sergio. Hypoglycemic effect of aerial parts on STZ-diabetic rats. Journal of Ethnopharmacology, 72, 2000, $129-133$.

[12] M. Carlson, P. Campbell. Intensive insulin therapy and weight gain in IDDM. Diabetes, 42 (12), 1993, $1700-1707$.

[13] N.D.G. Ibrahim, E. M. Abdurahman, G. Ibrahim. Histological studies on the effects of chronic feeding of Veronia amydalina De. Leaves on rats. Nigerian Journal of Surgical Research, 2 2000, 68-74.

[14] S. M. Ahmed, S. B. M. Vrushabendra, P. Gopkumar, R. Dhanapal and Chandrashekara. Antidiabetic activity of Terminalia Catappa linn. Leaf extracts in alloxan-induced diabetic rats. Iranian Journal of pharmacology and therapeutics, 4 (1), 2005, 38-39.

[15] H. U. Nwanjo, Free radicals scavenging potential of the aqueous extract of viscum album (mistletoe) leaves indiabetic wistar rats hapatoattes. The internel Journal of Nutrition and Wellness, 3 (2) 2007.

[16] Z. Kechrid and N. Bouzena. Effect of zinc deficiency and experimental diabetes on glustamate oxaloacetate, glutamate pyrurate aminotransferases and alkaline plosphatase activities in rat. Indain Journal of Diabetes and Metabolism, 11, 2004, 14-18.

[17] M. B. Nica, E. D. Linda, and W. H. Murray. Inhibition of Net Hep 92 cell apolipoproteins B secretion by the citrus flavonoid Naringenin involves activation of phosphatidylinositol 3-kinase. Diabetes 52, 2003, 255-2561.

[18] D. O. Edem, I. S. Ekanem, and P. E. Ebong. Effect of aqueous extract of alligator pear seed (persea Americana mill) on blood glucose and histopathology of pancreas in alloxan-induced diabetic rats._Pakistan Journal of Pharmaceutical Sciences, 22 (3), 2009 , $272-276$.

[19] B. Ragavan and S. Krishnmari. Effect of Terminalia arjuna_stem-bark extract on histopathology of liver, kidneys and pancreas of alloxan-induced diabetic rats. African journal of Biornedical Research, 9, 2006, 189 - 197.

[20] D. O. Adeyemi, O. A. Komolafe, S. O. Adewole E. M. Obuotor, and T. K. Adenowo. Effects of Annona Muncata Linn. On the morphology of pancreatic islet cells of experimentally induced diabetic wistar rats. The internet journal of Alternative Medicine, 5 (2), 2008.

[21] C. Sunil, P. G. Latha, S. R. Suja, V. J. Shine, S. Shyamal, G. I. Anuja, V. Kalichelvan. Effect of ethanolic extract of Pisonia alba span leaves on blood glucose levels and histological changes in tissues of alloxan-induced diabetic rats. International Journal of Applied Research in Natural Products, 2 (2), 2009, 4 - 11.

[22] G. Saravanan and I. Pari. Hypoglycemic and anti hyperglycemic effect of Syzygium cumini bark in streptozotoan -induced diabetic rats. Journal of Pharmaceolo and Toxicology3, 2008, 1-10.

[23] M. R. Zambare, U. A. Bhosale, R. S. Somani, R. Yegnanarayan and K. A. Talpate, A. Achyranthes aspera (Agadha). Herb that improves pabcreatic function in alloxain-induced diabetic rats. Asian Journal of Pharmaceutical and Biological Research 1, (2), $2011,99-104$.

[24] L. Luo, H. J. Yin, Y. Zhang, Y. R. Jiang, Y. Liu and D. Z. Shi. Effect of Gineseng fruit saponins on insulin sensitivity index in high fat-fed rats. Journal of Chinese Integrative Medicine, 3 (6), 2005, 463 - 465. 
[25] S. Bolkent, R. Yanardag, A. Tabakoghu-Oguz and Ozsoy-Sacan. Effect of chard (Beta Vulgaris L. var. cicla) extract on pancreatic beta cells in streptozotan - diabetic rats. A morphological and biochemical study. Journal of Ethnopharmacology, 73 (1-2), 2000, $251-259$.

[26] M. Diatewa, B. C. Samba, H. C. T Assah and A. A. Abena,. Hypoglycemic and antihyperghycemic effect of diethyl ether fraction isolated from the aqueous extract of the leaves of Cogniauxia podoleana baillion in normal and alloxan-induced diabetic rats. Journal of Ethnopharmacology, 92 2004, $229-232$.

[27] N. Singh, P. Verma, N. Mishara and R. Nath. A comparative evaluation of some anti-stress agents of plants origin. Indian Journal of pharmacology, 21 1991, 99.

[28] M. L. Mota, G. Thomas J, M. Barbosa. Antinflammantory actions of tannins isolated from the bark of Anacardium occidentale. Journal of Ethnopharmacology, 13 (13), 1985, 289-300.

[29] A. H. Tullo. "A. Nutty Chemical" Chemical and Engineering News, 86 (36), 2008, 26 - 27.

[30] J. Shabeer, R. S. Srivastava and S. K. Sing. Antidiabetic and antioxidant effect of various fractions of phyllanthus simplex in alloxan diabetic rats. Journal of Ethnopharmacology, 124, 2009, 34-38.

[31] K. D. Price C. S. Price and R. D.Reynolds. hyperglycemia-induced ascorbic acid deficiency promotes endothelial dysfunction and the development o atherosclerosis. Atherosclerosis, 158, 2001, 1-12.

[32] J. Valabhji A. J. McColl, W. Ridmond, M. Schachter, M. B. Rubens, R. S. Elkeles. Total antioxidant status and coronary artery calcification in type 1 diabetes. Diabetes Care, 24 (9), 2001, 1608-1613.

[33] A. D. Mooradian. Antioxidants and diabetes. Nestle Nutrition Workshop Series. Clinical and performance program, 11, 2006, 107122 .

[34] M. Tiedger, M. Lortz, J. Drinkgern, and S. Lenzen. Relation between antioxidant enzyme gene expression and antioxidative defense status of insulin producing cells. Diabetes, 46, 1997, 1733-1742.

[35] B. O'Connell. Selected vitamins and minerals in the management of diabetes. Diabetes Spectrum, 14 2001, 133-148.

[36] A. D. Mooradian, M. Failla, B. Hoogwerf, M. Maryniuk and J. Wylie-Rosett. Selected vitamins and minerals in diabetes. Diabetes Care, 17, 1994, $464-479$.

[37] G. Paolissco, S. Sgambato, G. Pizza, N. Passariello, M. Varricchio and F. D’Onofrio. Improved magnesium administration in aged NIDDM subjects. Diabetes Care, 12, 1989, 265-269.

[38] G. Paolisso, S. Sgamabato, A. Gambadella, G. Pizza, P. Tesauro, M. Varricchio and F. D’Onofrio. Daily magnesium supplements improve glucose handling in elderly subjects._American Journal of Clinical Nutrition, 55 1992, 1161 - 1167.

[39] A. H. Rubenstein, N. W. Iwin and G. A. Elliot. Manganese induced hypoghycemia. Lancet 2, $1995,134-1356$.

[40] G. Jelodar, M. Maleki, M. H. Motadayen and S. Sirus. Effect of Fenugreek, Onion and garlic on blood glucose and histopathology of pancreas of aloxan-indced diabetic rats. Idian Journal of Medical Sciences, 59 (2), 2005, 64 - 69.

[41] N. Takasu, T. Asawa, I. Komiya, Y. Nagasawa and I. Yamada. Alloxan-induced DNA trend breaks in pancreatic islets. Journal of Biological Chemistry, 266, 1991, $2112-2114$.

[42] C. F. Eliakim-Ikechuwu and A. I. Obri. Histological changes following administration of ethanolic extract of Alchonea Cordifila leaf in alloxan-induced diabetic wistar rats. Nigerian Journal of Physiological Society, 24 (2), 2009, 153-155.

[43] T. Bassey, C. Eliakim-Ikechukwu and C. Ihentuge. Effect of ethanolic stem-bark extract of Anacardium occidentale_(Cashew) on the histology of the pancreas of diabetic wistar rats. Journal of Biology, Agriculture and HealthCare, 2 (11), $2012,153-156$. 